\title{
Predation by sevenspine bay shrimp Crangon septemspinosa on winter flounder Pleuronectes americanus during settlement: laboratory observations
}

\author{
David A. Witting, Kenneth W. Able \\ Marine Field Station, Institute of Marine and Coastal Sciences, Rutgers University, 800 Great Bay Blvd, Tuckerton, \\ New Jersey 08087 , USA
}

\begin{abstract}
In laboratory experiments, we determined the relative amount of predation before, during and after settlement with winter flounder Pleuronectes americanus as prey and sevenspine bay shrimp Crangon septemspinosa as predators. Wild-caught winter flounder at various stages of morphological development and settlement [from presettled, pre-eye-migration ( $\leqslant 11 \mathrm{~mm}$ standard length, SL) to eyes fully migrated, settled individuals $(10.0$ to $34.3 \mathrm{~mm} \mathrm{SL})]$ were exposed to predation by adult shrimp ( 47 to $74 \mathrm{~mm}$ total length). Mortality in treatments involving small settled flounder ( $78 \%$ ) was twice that of presettled individuals ( 30 to $45 \%$ ). However, subsequent mortality decreased with flounder size, and was $0 \%$ for flounder $\geq 20 \mathrm{~mm}$ SL. Predator density affected rate of predation on settled juveniles $(8.7$ to $19 \mathrm{~mm} \mathrm{SL}$ ); mortality increased from 0 to $80 \%$ as predator density increased from 0 to $10.6 \mathrm{~m}^{-2}$ At densities $\geq 10.6 \mathrm{~m}^{-2}$, mortality reached an upper asymptote of 80 to $90 \%$. These experiments suggest that predation by shrimp may be an important determining factor of habitat selection, size and mortality during settlement of winter flounder and other benthic fishes
\end{abstract}

KEY WORDS: Predation - Settlement $\cdot$ Shrimp $\cdot$ Winter flounder

\section{INTRODUCTION}

Understanding the relationship between body size, developmental stage and the processes that regulate fish recruitment may be central to the successful prediction of population abundance (Miller et al. 1988). This more dynamic approach has caused the original concept of the 'critical period' by Hjort (1914) to be redefined as a gauntlet involving a series of ontogenetic bottlenecks in which predation plays an important role (Bailey \& Houde 1989, Bailey 1994). In an effort to develop a conceptual framework that defines the role of predation during fish ontogeny, Bailey \& Houde (1989) characterized predators based upon their methods of encountering, detecting, and subduing prey and presented conceptual models describing the relationship between larval size and vulnerability to different types of predators. These models were based upon a combined probability of larval encounter and susceptibility to capture. In some cases, the shapes of these vulnerability curves have been verified experimentally (Bailey \& Yen 1983, Folkvord \& Hunter 1986, de Lafontaine \& Leggett 1988, Cowan \& Houde 1993). Much of this effort has focused on larval stages, primarily due to the high mortality that they suffer (Hjort 1914). However, a growing volume of literature suggests that processes affecting the late-larval/early juvenile stages may be important in determining year class strength (Sissenwine 1984, van der Veer 1986, Victor 1986, van der Veer \& Bergman 1987, Chambers et al. 1988, Peterman et al. 1988, Rice et al. 1993, Bailey 1994).

Many predation models assume that a successful predation event is the product of 3 probabilities (Gerritsen \& Strickler 1977, O'Brien 1979): (1) the predator must encounter the prey, (2) the predator must elect to attack the prey, and (3) the attack must be successful. Several factors have been shown to affect each of these proba- 
bilities. Prey encounter rates have been related to predator reactive distance and prey swimming speed (Gerritsen \& Strickler 1977), which, in turn, are affected by predator and prey body size and the methods by which the predators detect their prey (Bailey \& Houde 1989). The rate of successful attacks tends to decrease with increasing prey/predator size ratio (Krebs 1978). The probability that a predator will attack after encountering a potential prey, however, can be complicated by predator choice (Litvak \& Leggett 1992), which may be largely determined by the ratio of the nutritional value and handling time of the prey (Krebs 1978). In addition, many predator-prey models are based on the assumption that as fish grow, the suite of potential predators they encounter remains static. Predator fields can change as a function of body size. For many fishes, major changes in habitat occur during the first few months of life, and each habitat change may be coupled with a change in predator fields (Werner 1986). Flatfishes, in particular, shift from a pelagic to a benthic habitat largely in synchrony with their morphological metamorphosis (see Markle et al. 1992 for some exceptions). Species composition of pelagic predators (e.g. jellyfish, pelagic fishes) usually differs from that of benthic predators (shrimp, crabs, and benthic fishes). These differences in predator species may also produce a difference in mode of attack (i.e. use of substrate for hiding), although data comparing benthic versus pelagic predator types are rare. It is clear that benthic predators (especially crabs and shrimp) can occur in high densities and pose a significant threat to survival of small, settling flatfish (Edwards \& Steele 1968, Lockwood 1980, van der Veer \& Bergman 1987).

Winter flounder Pleuronectes americanus is a medium-sized (maximum $45 \mathrm{~cm}$ standard length, SL), pleuronectid fish inhabiting estuaries and the continental shelf of northeast North America (Scott \& Scott 1988). Spawning of demersal eggs occurs in estuaries during the winter and early spring (Pearcy 1962). After hatching, the larvae are pelagic for approximately $60 \mathrm{~d}$ (Chambers \& Leggett 1987), but the duration of this period can vary significantly depending on temperature (Laurence 1975). Loss during the pelagic phase has been attributed to transport from the estuary and predation by a variety of pelagic predators such as the hydromedusa Sarsia tubulosa (Pearcy 1962). Although there is little field information about growth rate of settling individuals, laboratory studies suggest that premetamorphic growth rate is inversely related to postmetamorphic growth rate (Chambers et al. 1988, Bertram et al. 1993). After settlement, growth rate estimates for juvenile winter flounder ( 25 to $40 \mathrm{~mm} \mathrm{SL}$ ) in southern New Jersey, USA, ranged from 0 to $1 \mathrm{~mm} \mathrm{~d}^{-1}$ in caging experiments (Sogard 1992) and from 0.5 to $1.2 \mathrm{~mm} \mathrm{~d}^{-1}$ from back calculation of growth rate from interincrement distances on the otolith microstructure (Sogard \& Able 1992).

A potential predator of larval and juvenile winter flounder, the sevenspine bay shrimp Crangon septemspinosa is common to the estuaries and continental shelf of northeast North America from the Gulf of Saint Lawrence to eastern Florida and is abundant in the northern part of this range (Haefner 1979). This shrimp exhibits only minor morphological differences from the brown shrimp Crangon crangon of Europe (Haefner 1979), which is an important predator of juvenile plaice Pleuronectes platessa (van der Veer \& Bergman 1987, Bergman et al. 1989, van der Veer et al. 1991) and flounder Platichthys flesus (van der Veer et al. 1991) Sevenspine bay shrimp are most abundant in the lower reaches of estuaries and are seldom collected in salinities of less than 10\% (Haefner 1979). Seasonally, they have 2 peaks in abundance, one in spring and a less distinct peak in autumn (Price 1962, Modlin 1980). Shrimps of the genus Crangon are generally considered omnivorous, nocturnal predators that bury during the day (Haefner 1979). They feed primarily upon mollusks, arthropods, and annelids, but also upon fish (Wilcox \& Jeffries 1974, van der Veer \& Bergman 1987 , Witting \& Able 1993, Bertram \& Leggett 1994). Generally considered benthic, shrimp in this genus can at times be pelagic as well (Dodson et al. 1989).

In previous laboratory experiments (Witting \& Able 1993), we demonstrated that susceptibility of juvenile winter flounder to predation by the sevenspine bay shrimp decreases dramatically with increasing flounder size. Bertram \& Leggett (1994) showed that at metamorphosis, variation in age and size had little effect on vulnerability to predation and concluded that an examination of vulnerability, from metamorphosis through the early juvenile period, was neccesary to completely understand the role of predation. Our earlier experiments were designed only to investigate the outcome when a predator encountered a benthic prey (i.e. the second of 3 components of a predation event mentioned above). The probability of a floundershrimp encounter (i.e. the first component), however, does not remain constant over the early life history of the fish. In this paper, we develop the conceptual model suggested by Bailey \& Houde (1989) for ambush raptorial predators on fish larvae. Our model suggests that the habitat shift experienced during the transition from the water column to the substrate during settlement has important effects upon the shape of the vulnerability curve of settling flatfish to 1 group of predators (shrimp). With laboratory experiments we attempt to determine first, whether the probability of a winter flounder encountering a shrimp increases during settlement, and second, how predator density affects vulnerability after settlement. 


\section{METHODS}

Experimental specimens and handling. We collected larval winter flounder under nightlights at the Rutgers University Marine Field Station in Great Bay $\left(39^{\circ} \mathrm{N}, 74^{\circ} \mathrm{W}\right)$, New Jersey. Most of the flounder were captured before eye migration and maintained in the laboratory so that larvae and juveniles of all settlement/eye-migration stages and sizes were available for experiments. All flounder were maintained in 391 aquaria that were immersed in an ambient temperature flow-through seawater bath, and fed recently hatched Artemia nauplii. Prior to experiments, we measured flounder standard length to the nearest $0.1 \mathrm{~mm}$ using an ocular micrometer after anesthetization in MS-222 (20 $\mathrm{mg} \mathrm{l}^{-1}$ ). We determined developmental stage of all fish based on the degree of hypural development and notochord flexion for pre-eye-migration larvae, and degree of eye migration (Table 1).

Adult shrimp were collected from the same estuary using a bag seine and transported immediately to the laboratory where they were maintained in large flowthrough tanks containing $5 \mathrm{~cm}$ of sand and $10 \mathrm{~cm}$ of seawater. All shrimp were fed chopped fish and shrimp daily. To ensure that all shrimp experienced similar levels of hunger during the experiments, we separated the shrimp, provided them with equal quantities of food for $1 \mathrm{~h}$, and then introduced them to the experimental containers without food for $24 \mathrm{~h}$ prior to each experiment. This period of starvation is consistent with previous laboratory experiments using sevenspine bay shrimp as predators (Olmi \& Lipcius 1991). Prior to each experiment, total length (TL) of all shrimp was measured from the tip of the antennal scale to the end of the telson (Price 1962).

Table 1. Pleuronectes americanus. Description of winter flounder stages used in settlement experiments as modified from Ryland (1966)

\begin{tabular}{|c|c|}
\hline Stage & Description \\
\hline 2 & $\begin{array}{l}\text { Eyes symmetrical; notochord straight; rudimentary } \\
\text { hypurals developing; yolk absorbed }\end{array}$ \\
\hline $3 b$ & Eyes symmetrical; notochord upturned $\left(45^{\circ}\right.$ to $\left.90^{\circ}\right)$ \\
\hline $3 c$ & $\begin{array}{l}\text { Eyes symmetrical; notochord turned straight } \\
\text { upwards; marginal fin-rays becoming fully } \\
\text { developed }\end{array}$ \\
\hline $4 a$ & $\begin{array}{l}\text { Eyes asymmetrical, but left eye not visible from the } \\
\text { right side }\end{array}$ \\
\hline $4 b$ & $\begin{array}{l}\text { Left eye visible over top of head when viewed from } \\
\text { the right side }\end{array}$ \\
\hline 5 & $\begin{array}{l}\text { Left eye on the edge of head, the pupil visible from } \\
\text { the top }\end{array}$ \\
\hline 6 & Eye migration complete \\
\hline
\end{tabular}

Modeling the predator-prey relationship. To model the predator-prey relationship between winter flounder and shrimp, we used a conceptual approach based on the encounter rate and the likelihood of a successful capture after an encounter occurs (Bailey \& Houde 1989). The primary assumptions of this model are: (1) as fish grow the probability of settlement increases, (2) settlement sizes are distributed normally around a mean size, and (3) as fish settle, the probability of encountering a benthic shrimp increases in proportion to the amount of time the fish spends near or on the substrate. The third assumption is based upon the fact that sevenspine bay shrimp are primarily benthic, thus their densities on the substrate are much greater than in the water column. The probability of encounter was described by the error function (Tuma 1989) that approximates the area under a normal curve, thus as a fish increases in size, the probability of settling increases as well. This produces a sigmoid curve with an inflection point at the center of the distribution. Thus we used the error function, modified by a few parameters:

$$
P_{\mathrm{e}}=D+\frac{A}{2} \operatorname{erf}[b(\mathrm{SL}-c)]
$$

where $P_{e}$ is the probability of a predator-prey encounter between a shrimp and a flounder, $D$ sets the vertical position of the curve's inflection point (i.e. the size at which the flounder spends $50 \%$ of the time on the substrate, $c), A$ is the difference between the probability of a pelagic versus a benthic flounder encountering a shrimp, erf is the error function of the bracketed expression, and $b$ is a parameter that determines the size range over which settlement occurs.

In order to produce parameters that are more realistic, we used separate probabilities of a flounder encountering a shrimp in the plankton $\left(P_{\mathrm{p}}\right)$ or on the substrate $\left(P_{\mathrm{s}}\right)$, thus producing our final equation:

$$
P_{\mathrm{e}}=\left(\frac{P_{\mathrm{s}}-P_{\mathrm{p}}}{2}+P_{\mathrm{p}}\right)+\left(\frac{P_{\mathrm{s}}-P_{\mathrm{p}}}{2}\right) \operatorname{erf}[b(\mathrm{SL}-c)]
$$

To produce a hypothetical mortality curve for laboratory experiments, we set the probability of encounter to $1\left(P_{\mathrm{s}}=1\right)$ on the substrate, and $0.1\left(P_{\mathrm{p}}=0.1\right)$ in the plankton. This produces a 10 -fold change in probability of encounter before and after metamorphosis and associated habitat shift. Because the shrimp are primarily benthic, we believe this is quite reasonable. Substituting 0.5 for $b$ and 11 for $c$ produces a similar pattern reported from laboratory observations (Chambers \& Leggett 1987) where winter flounder settlement begins at just over $8 \mathrm{~mm}$ SL and is complete at about $13 \mathrm{~mm}$ SL (Fig, 1a).

We predicted a successful capture (susceptibility; Bailey \& Houde 1989) of a flounder by a shrimp using 


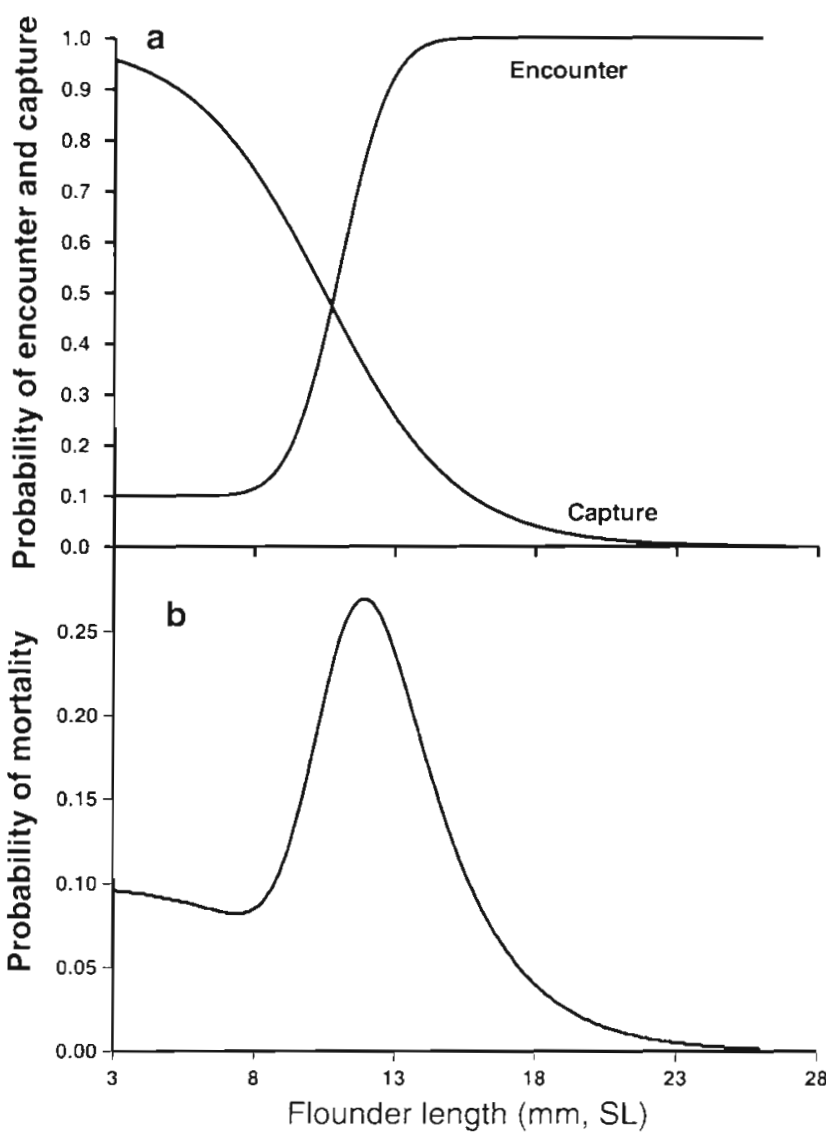

Fig. 1. Crangon septemspinosa preying on Pleuronectes americanus. Relationship predicted by a model (see text) between (a) probability of encounter between sevenspine bay shrimp and winter flounder and capture after an encounter, and, (b) mortality due to predation by shrimp relative to flounder size

a logistic regression model (Witting \& Able 1993, Fig. 1a):

$$
\text { Logit }=4.39-(0.42 \times \mathrm{SL})
$$

where the logit is the natural log of the ratio of probabilities of mortality and survival of the individual. Because the sum of these 2 probabilities is unity, we can then calculate the probability of mortality after an encounter occurred.

The probability of both an encounter and a capture occurring is the product of the 2 probabilities (i.e. vulnerability, the product of Eqs. 1 \& 3). After multiplication, the resultant vulnerability curve was dome shaped with a peak at settlement, followed by a rapid decrease after settlement (Fig. 1b). This hypothetical relationship is based on the primarily benthic nature of the shrimp, although they can occasionally be pelagic (Dodson et al. 1989). The magnitude of the increase in probability of encounter may be affected by several factors (e.g. predator and prey density, habitat struc- ture), but only predator density effects are addressed here.

Effect of flounder size and stage on predation. To determine how the risk of predation by adult shrimp varied with flounder size and developmental stage, we conducted a single-factor experiment with flounder stage as the treatment (Table 2). We intentionally allowed some overlap in flounder sizes between treatments to approximate the continuous nature of metamorphosis and settlement. However, the mean sizes between treatments were all significantly different (Student-Newman-Keuls procedure, critical $\alpha=0.05$ ) as were the distribution of flounder stages $\left(\chi^{2}=100, p \leqslant\right.$ 0.01 ). We used shrimp of similar size (range $=47$ to $74 \mathrm{~mm} \mathrm{TL}$; Table 2) to avoid confounding the size effect of prey with that of predators. Early larval flounder (prior to stage 5) were staged but not measured in order to reduce the possibility of mortality due to handling. The sizes of the smaller larvae were estimated from mean sizes of live specimens. This experiment was conducted in 12 cylindrical plastic containers $(55.9 \mathrm{~cm}$ high, $53.3 \mathrm{~cm}$ diameter, $69.4 \mathrm{l}$ volume) with $2 \mathrm{~cm}$ of clean sand [grain size 0.187 ( $\pm 0.007 \mathrm{SD}$ ) $\mathrm{mm}, 0.89 \%$ silt/clay] on the bottom. Each container was filled to a water depth of $52 \mathrm{~cm}$ and included an air stone to provide aeration and water movement. Each experimental run was performed with a different flounder size/ stage treatment, because adequate quantities of the entire range of sizes and stages were unavailable at any single time. To each of 10 experimental containers 3 shrimp $\left(13.4 \mathrm{~m}^{-2}\right)$ and 5 flounder $\left(22.4 \mathrm{~m}^{-2}\right)$ were added. Two containers were left without shrimp predators as controls for mortality due to factors other than predation. Before the flounder were released into the containers, they were staged, measured, and then placed in round plastic bowls with excess quantities of Artemia sp. for food. The bowls were floated in individual experimental containers for $24 \mathrm{~h}$, allowing for a starvation period for the shrimp already in the experimental containers and a feeding period for the flounder in the bowls. After the starvation/feeding period, flounder were visually examined to establish that all had fed. We then gently introduced the flounder into their respective experimental containers. Predators and prey were then allowed to interact for $24 \mathrm{~h}$. After this period, we recorded water temperature with a stem thermometer, removed the shrimp, and searched the containers for surviving flounder. This was done first by examining the container using a spotlight, then by pouring the water through a $0.5 \mathrm{~mm}$ mesh sieve. Salinity for all experiments ranged from 30 to $33 \%$. Experimental runs were made between 5 May and 25 June 1991

Effect of predator density on mortality. To test the effect of shrimp density on mortality of settled winter flounder, we used a single-factor experiment with 
Table 2. Pleuronectes americanus preyed on by Crangon septemspinosa. Sizes and stages of winter flounder and sevenspine bay shrimp used for each run of the settlement experiments. Temperatures are given for the time at flounder introduction and the range of temperature during each treatment. Means and ranges estimated from other flounder that were measured live

\begin{tabular}{|c|c|c|c|c|c|c|}
\hline Run & $\begin{array}{l}\text { No. of } \\
\text { flounder }\end{array}$ & $\begin{array}{l}\text { Floun } \\
\text { (sam }\end{array}$ & $\begin{array}{l}\text { stages } \\
\text { e size) }\end{array}$ & $\begin{array}{c}\text { Flounder length (mm SL) } \\
\text { Mean (range) }\end{array}$ & $\begin{array}{l}\text { Shrimp length (mm TL) } \\
\text { Mean (range) }\end{array}$ & $\begin{array}{c}\text { Temperature }\left({ }^{\circ} \mathrm{C} \text { ) }\right. \\
\text { Mean (range) }\end{array}$ \\
\hline 1 & 49 & $\begin{array}{l}2 \\
3 b \\
3 c\end{array}$ & $\begin{array}{r}(16) \\
(30) \\
(3)\end{array}$ & $\begin{array}{c}6.5^{\circ} \\
(5.8-7.2)^{\circ}\end{array}$ & $\begin{array}{c}56.0 \\
(51-74)\end{array}$ & $\begin{array}{c}13.3 \\
(10.8-14.9)\end{array}$ \\
\hline 2 & 50 & $\begin{array}{l}4 \mathrm{a} \\
4 \mathrm{~b}\end{array}$ & $\begin{array}{l}(40) \\
(10)\end{array}$ & $\begin{array}{c}7.1^{\circ} \\
(6.2-8.0)^{\circ}\end{array}$ & $\begin{array}{c}56.0 \\
(50-65)\end{array}$ & $\begin{array}{c}15.4 \\
(13.4-16.5)\end{array}$ \\
\hline 3 & 50 & 5 & $(50)$ & $\begin{array}{c}9.0 \\
(7.5-10.9)\end{array}$ & $\begin{array}{c}54.9 \\
(49-66)\end{array}$ & $\begin{array}{c}18.3 \\
(18.1-18.5)\end{array}$ \\
\hline 4 & 50 & $\begin{array}{l}5 \\
6\end{array}$ & $\begin{array}{r}(1) \\
(49)\end{array}$ & $\begin{array}{c}11.9 \\
(10.1-14.5)\end{array}$ & $\begin{array}{c}54.5 \\
(48-61)\end{array}$ & $\begin{array}{c}21.0 \\
(20.8-21.5)\end{array}$ \\
\hline 5 & 50 & 6 & $(50)$ & $\begin{array}{c}14.9 \\
(12.9-17.7)\end{array}$ & $\begin{array}{c}53.0 \\
(47-61)\end{array}$ & $\begin{array}{c}20.1 \\
(18.6-21.2)\end{array}$ \\
\hline 6 & 50 & 6 & $(50)$ & $\begin{array}{c}18.8 \\
(16.3-22.4)\end{array}$ & $\begin{array}{c}55.3 \\
(49-65)\end{array}$ & $\begin{array}{c}19.2 \\
(18.4-19.5)\end{array}$ \\
\hline 7 & 45 & 6 & (45) & $\begin{array}{c}26.0 \\
(21.3-34.3)\end{array}$ & $\begin{array}{c}52.6 \\
(47-61)\end{array}$ & $\begin{array}{c}21.3 \\
(18.7-20.8)\end{array}$ \\
\hline
\end{tabular}

shrimp density $\left(0,2.4,10.6,21.2,30.6\right.$, and $\left.41.2 \mathrm{~m}^{-2}\right)$ as a treatment (Table 3). Shrimp were distributed randomly with respect to size in the treatments to eliminate the confounding effects of predator size and prey density. Each density treatment was replicated twice per run. In these experiments, temperature could not be controlled; however, all density treatments were represented in all runs, so that the effect of temperature was evaluated by treating it as a covariate. Runs 1 and 4 were performed under similar temperatures $(22.7 \pm 0.04$ and $23.1 \pm$

Table 3. Crangon septemspinosa preying on Pleuronectes americanus. Sizes of sevenspine bay shrimp and winter flounder used in predator density experiments. Initial flounder density was constant at $5.9 \mathrm{~m}^{-2}$ ( 5 flounder)

\begin{tabular}{|ccc|}
\hline $\begin{array}{c}\text { Number of } \\
\text { shrimp } \\
\text { (density, no. } \mathrm{m}^{-2} \text { ) }\end{array}$ & $\begin{array}{c}\text { Shrimp length } \\
\text { (mm TL) } \\
\text { Mean (range) }\end{array}$ & $\begin{array}{c}\text { Flounder length } \\
\text { (mm SL) } \\
\text { Mean (range) }\end{array}$ \\
\hline 0 & - & 13.1 \\
$2(2.4)$ & 54 & $(10.0-16.2)$ \\
& $(45-66)$ & 12.7 \\
$9(10.6)$ & 51 & $(9.7-16.3)$ \\
& $(43-71)$ & 13.3 \\
$18(21.2)$ & 51 & $18.7-18.1)$ \\
& $(41-62)$ & $(10.1-16.0)$ \\
$26(30.6)$ & 51 & 13.6 \\
$35(41.2)$ & $(42-65)$ & $(10.3-19.0)$ \\
& 51 & 13.6 \\
& $(41-67)$ & $(9.0-18.3)$ \\
\hline
\end{tabular}

$\left.0.05^{\circ} \mathrm{C}\right)$ as were Runs 2 and $3(18.4 \pm 0.04$ and $18.3 \pm$ $0.04^{\circ} \mathrm{C}$ ). These runs, conducted between 30 May and 20 June 1991, were combined into warm runs (1 \& 4) and cold runs $(2 \& 3)$ for analysis of temperature effects. We used large pools $\left(100 \mathrm{~cm}\right.$ diameter, $18 \mathrm{~cm}$ depth, $0.85 \mathrm{~m}^{2}$ bottom area) with $2 \mathrm{~cm}$ of clean sand on the bottom, filled with seawater to a depth of $12 \mathrm{~cm}$, and a single air stone in each to provide aeration and water movement. Pools were set up outdoors in a shaded area, so that individuals experienced a natural day/night cycle (15 h:9 h).

For each experimental run, 5 flounder were measured and placed in bowls to feed before release as in the previous experiment. All flounder had completed eye migration (stage 6) and their sizes were characteristic of immediately settled winter flounder (Table 3). The flounder were introduced to the pools and then observed briefly (about $2 \mathrm{~min}$ ) to see if predation occurred immediately after introduction. Pools were then covered with screens that allowed light to pass, but eliminated the possibility of loss due to fish jumping out or predation by birds. After $24 \mathrm{~h}$, we removed the covers and searched the pools for surviving flounder and shrimp using a spotlight. We measured all survivors in order to test for differential mortality of smaller winter flounder.

\section{RESULTS}

\section{Effect of flounder size and stage on predation}

All but the largest, postsettlement winter flounder were preyed upon by sevenspine bay shrimp, with the 


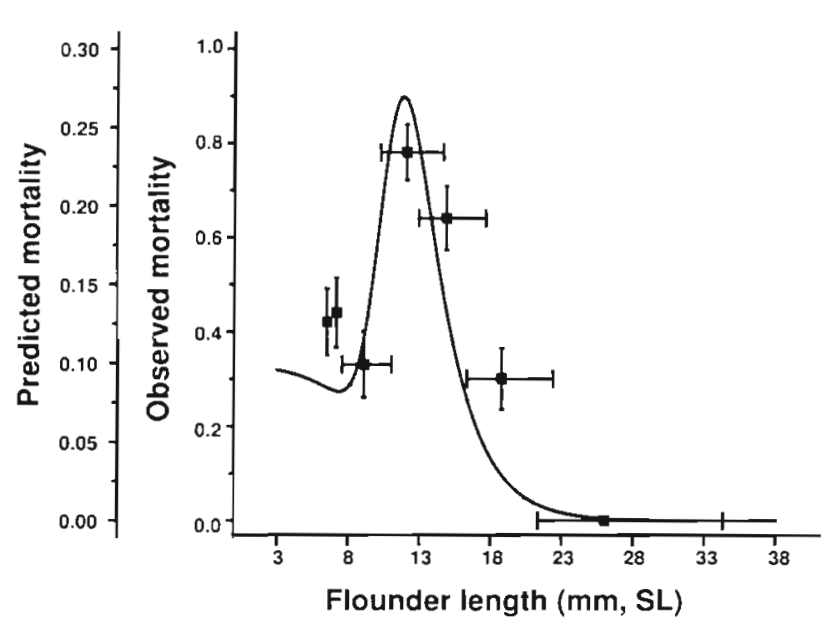

Fig. 2. Crangon septemspinosa preying on Pleuronectes americanus. Relationship between size and mortality of winter flounder during settlement due to predation by sevenspine bay shrimp in laboratory experiments. Solid curve: mortality predicted from model (Fig. 1b). (曰) Observed mortality (vertical error bars $= \pm \mathrm{SE}$ ) and standard length (horizontal error bars $= \pm$ SE)

highest mortality for flounder that had recently settled (Fig. 2). Prior to stage 6 (before eye migration or eye migration incomplete, $\leq 11 \mathrm{~mm} \mathrm{SL}$ ), approximately 30 to $45 \%$ of the flounder were preyed upon. For treatments including primarily stage 6 individuals (i.e. flounder that had completed eye migration and settlement, 10.1 to $14.5 \mathrm{~mm} \mathrm{SL}$ ), predation averaged $78 \%$. We analyzed for the effect of prey size and temperature on mortality of winter flounder with a logistic regression analysis, which tests for the effect of continuous variables on a discrete response using a model where the response, in this case, is the log of the ratio of the number of fish alive or dead (Witting \& Able 1993). Based on logistic regression, the increase in mortality was highly significant $\left(\chi^{2}=31.42, p \leqslant 0.01\right)$ and occurred at a similar size as in the model (Fig. 2). As flounder size increased after settlement, mortality decreased and reached zero when the flounder were approximately 20 to $35 \mathrm{~mm} \mathrm{SL}$. This decrease in mortality fits the pattern predicted by the madel (Fig. 2).

\section{Effects of predator density on predation}

In the density experiments, mortality increased from 0 (in treatments with no predators) to $100 \%$ in some high-density treatments (Fig. 3). At predator densities of $\geq 10.6 \mathrm{~m}^{-2}$ (Fig. 3), mortality varied from 80 to $100 \%$ with no significant differences between densities. However, at predator densities $<10.6 \mathrm{~m}^{-2}$, mortality dropped rapidly to approximately $30 \%$ for a density of $2.4 \mathrm{~m}^{-2}$. In this experiment, both temperature and den-

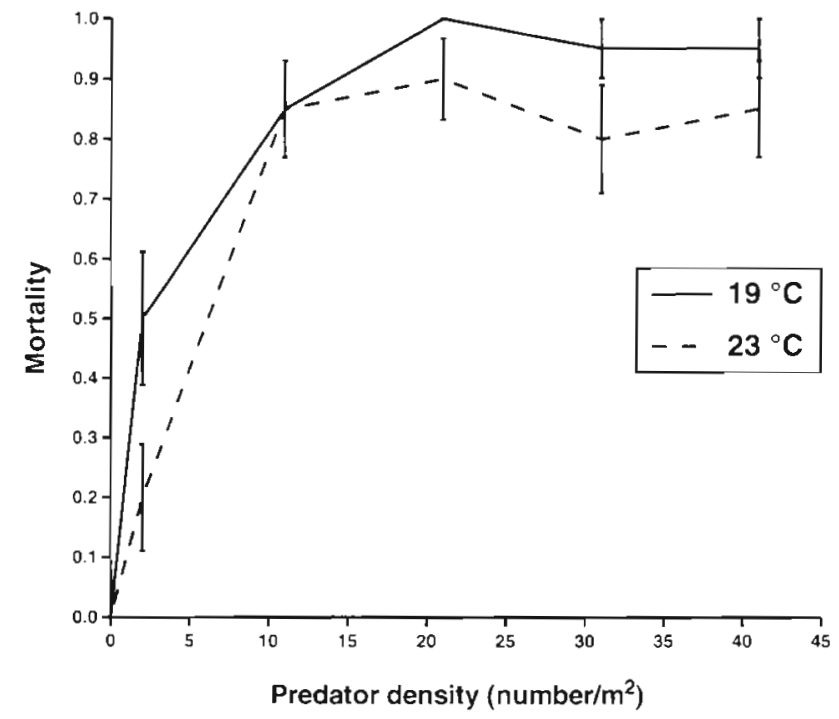

Fig. 3. Crangon septemspinosa preying on Pleuronectes americanus. Relationship between sevenspine bay shrimp density and mortality of winter flounder in laboratory experiments at 2 temperatures $\left(19\right.$ and $\left.23^{\circ} \mathrm{C}\right)$

sity were significant, the temperature effect negative $\left(\chi^{2}=5.74, p<0.02\right)$ and the density effect positive $\left(\chi^{2}=24.48, p \ll 0.01\right)$. Slightly higher mortality was observed in the low temperature runs than in the warm runs (Fig. 3).

We examined the mortality within $1 \mathrm{~mm}$ flounder length classes to determine whether or not mortality was size specific. We only used those treatments where shrimp density was $\geq 10.6 \mathrm{~m}^{-2}$ because mortality did not vary significantly between these treatments. Logistic regression suggested that size had a significant effect on mortality $\left(\chi^{2}=11.19, p \ll 0.01\right.$, logit $=9.59$ $0.53 \mathrm{SL}$ ) that resulted in decreased mortality on larger flounder (Fig. 4). No mortality was observed for flounder $\geq 19 \mathrm{~mm}$. SL.

\section{DISCUSSION}

The results of these laboratory experiments suggest that larval and recently settled winter flounder may suffer significant levels of mortality due to predation by sevenspine bay shrimp. Further, the vulnerability to these shrimp peaks at settlement, when winter flounder are completing several aspects of morphological and ecological metamorphosis (i.e. eye migration, scale development and a shift from pelagic to benthic habitat). The results of both these experiments and previous laboratory experiments (Witting \& Able 1993), all 3 of which were conducted in different container sizes and at different levels of predator and prey density, suggest a decrease in vulnerability after settle- 
ment with a size refuge at $>20 \mathrm{~mm}$ SL. Similar patterns of mortality due to predation upon settled plaice Pleuronectes platessa by another species of Crangon have been demonstrated (Edwards \& Steele 1968, Lockwood 1980, van der Veer \& Bergman 1987, Pihl 1990, van der Veer et al. 1991). In fact, predation upon juvenile plaice by C. crangon has been implicated as the cause of significant density-dependent mortality during the early juvenile period (van der Veer \& Bergman 1987).

The effect of stage and size on predation is consistent with the exposure to new predators experienced by winter flounder during settlement under natural conditions. This transition and resulting mortality due to predation may significantly affect the distribution and abundance of winter flounder within nursery estuaries. Previous work has shown that, in the absence of a water column, winter flounder vulnerability simply declines with increasing prey size (Witting \& Able 1993) but that variation in age or size at metamorphosis does not affect vulnerability (Bertram \& Leggett 1994). Our current model includes a change in probability of encounter during settlement, producing a dome-shaped vulnerability curve. These data suggest that the ontogenetic gauntlet does not end with the larval period, but that the transition into the juvenile period may also include important sources of mortality that regulate recruitment. Prior to settlement, vulnerability to predation by ambush raptorial predators upon fish larvae has also been shown to be dome shaped with respect to prey body size (Bailey \& Yen 1983, Bailey \& Houde 1989), due to the predators' inability to detect small and/or inactive prey and to capture larger prey. In addition, most work with larvae has shown decreased vulnerability to predation as they approach the juvenile period (Bailey \& Houde 1989). However, at the onset of the juvenile period, benthic species may experience an increase in mortality associated with settlement that is independent of mortality experienced during the larval period.

These data support the hypothesis that flounder settling at larger sizes or those that grow faster after settlement may have an improved chance of survival (Chambers et al. 1988), at least when shrimp predators are abundant. Increased survival of larger winter flounder is probably due to increased handling time by the predator, combined with increased escape responses of the winter flounder (Williams \& Brown 1992). An obvious question that results from this exper- iment is: why do winter flounder settle at such a small size? This question may be partly explained by considering the transition from pre- to postsettlement sources of mortality. During a habitat shift, a fish will avoid prior sources of mortality in the former habitat and encounter new sources in the latter (Werner et al. 1983, Werner 1986, Mittelbach \& Chesson 1987). For settling flatfishes, mortality can be affected by a combination of biotic and abiotic factors. In some cases, settlement can be delayed until the appropriate size, age, or habitat requirements are encountered (Markle et al. 1992). The extent to which settlement can be delayed, however, may be largely controlled by the trade off between pre- and postsettlement sources of mortality.

Three important sources of mortality for winter flounder are likely to increase with duration in the pelagic habitat: (1) increased probability of detection by visual predators with increased size and pigmentation (Litvak \& Leggett 1992), (2) increased probability of encountering predators with increased swimming speed and activity levels (Bailey \& Houde 1989), and (3) increased cumulative probability of being flushed out of estuarine nurseries (Pearcy 1962). The last may be especially important to winter flounder, as well as other estuarine-spawned flatfish, which settle at comparatively smaller sizes than many other flatfishes (Miller et al. 1991). Also during settlement, the size and species composition of the winter flounder prey community are likely to change. The prey community on the 2-dimensional sediment surface may be easier to 
encounter, more dense, and thus more conducive to fast growth than in the 3-dimensional pelagic habitat, thus allowing a fish to more quickly achieve a size refuge from its predators.

The results of the predator density experiments demonstrated that at densities $>10.6$ shrimp $\mathrm{m}^{-2}$, risk of predation on settled winter flounder was high ( $>80 \%$ probability of mortality). Even at a shrimp density $\leq 2.4 \mathrm{~m}^{-2}$, risk of predation is considerable (about $30 \%$ probability of mortality). These data suggest that the encounter curve (Eq. 2 of the model Fig. 1) remains approximately the same for shrimp densities $>10.6 \mathrm{~m}^{-2}$. In New Jersey estuaries, adult shrimp densities typically vary between 0 and $10 \mathrm{~m}^{-2}$ during the period of winter flounder settlement, although densities of $>30 \mathrm{~m}^{-2}$ do occur (Witting \& Able pers. obs.). Thus, risk of predation by sevenspine bay shrimp may vary dramatically between habitats. This variation in risk of predation between habitats could be critical in determining the quality of estuarine nursery habitats for winter flounder, and potentially the small juveniles of other benthic fishes as well.

In summary, our results support the hypothesis that the habitat shift experienced by winter flounder at settlement may have important effects upon mortality. These experiments focused on shrimp as predators, but several other co-occurring benthic crustaceans may produce a similar relationship, including several species of crabs such as green crabs Carcinus maenas (van der Veer \& Bergman 1987), blue crabs Callinectes sapidus (Reichert \& van der Veer 1991, Witting \& Able pers. obs.), rock crabs Cancer irroratus and lady crabs Ovalipes ocellatus (Witting \& Able pers. obs.). An increase in probability of encounter with shrimp predators followed by the establishment of a size refuge from predation resulted in a dome-shaped vulnerability curve relative to body size with a peak at settlement. As fish shift from one predator field to the next during ontogeny, the shapes of the vulnerability curves for each consecutive field will have important effects upon cumulative mortality over the entire early life history.

Acknowledgements. A number of individuals from the Rutgers University Marine Field Station provided assistance. We thank M. Pearson and L. Wulff for assistance in setting up and conducting laboratory experiments, and P. Halupa and B. Zlotnik for help with manuscript preparation. C. Chambers and 2 anonymous reviewers made valuable comments on earlier drafts. Funding for this work was provided by the Electnc Power Research Institute (EPRI) COMPMECH key species program, the Manasquan Marlin and Tuna Club, the Leatham Fund, Biological Sciences, Rutgers University, and the Institute of Marine and Coastal Sciences (IMCS), Rutgers University. This is IMCS contribution number 95-13.

\section{LITERATURE CITED}

Bailey KM (1994) Predation on juvenile flatfish and recruitment variability. Neth J Sea Res 32(2):175-189

Bailey KM, Houde ED (1989) Predation on eggs and larvae of marine fishes and the recruitment problem. Adv mar Biol 25:1-83

Bailey KM, Yen J (1983) Predation by a carnivorous marine copepod, Euchaeta elongata Esterly, on eggs and larvae of the Pacific hake, Merluccius productus. J Plankton Res 5(1):71-82

Bergman MJN, van der Veer HW, Zijlstra JJ (1989) Plaice nurseries: effects on recruitment. J Fish Biol 33:201-215

Bertram DF, Chambers RC, Leggett WC (1993) Negative correlations between larval and juvenile growth rates in winter flounder: implications of compensatory growth for variation in size-at-age. Mar Ecol Prog Ser 96:209-215

Bertram DF, Leggett WC (1994) Predation risk during the early life history periods of fishes: separating the effects of size and age. Mar Ecol Prog Ser 109:105-114

Chambers RC, Leggett WC (1987) Size and age at metamorphosis in marine fishes: an analysis of laboratory-reared winter flounder (Pseudopleuronectes americanus) with a review of variation in other species. Can J Fish Aquat Sci $44: 1936-1947$

Chambers RC, Leggett WC, Brown JA (1988) Variation in and among early life history traits of laboratory-reared winter flounder Pseudopleuronectes americanus. Mar Ecol Prog Ser $47: 1-15$

Cowan JH Jr, Houde ED (1993) Relative predation potentials of scyphomedusae, ctenophores and planktivorous fish on ichthyoplankton in Chesapeake Bay. Mar Ecol Prog Ser 95:55-65

de Lafontaine Y, Leggett WC (1988) Predation by jellyfish on larval fish: an experimental evaluation employing in situ enclosures. Can J Fish Aquat Sci 45:1173-1190

Dodson JJ, Dauvin J, Ingram RG, D'Anglejan B (1989) Abundance of larval rainbow smelt (Osmerus mordax) in relation to the maximum turbidity zone and associated macroplankton fauna of the middle St. Lawrence estuary. Estuaries 12(2):66-81

Edwards R, Steele $J$ (1968) The ecology of 0-group plaice and common dab at Loch Ewe. I. Population and food. J exp mar Biol Ecol 2:215-238

Folkvord A, Hunter JR (1986) Size-specific vulnerability of northern anchovy, Engraulis mordax, larvae to predation by tishes. Fish Bull 84(4):859-869

Gerritsen J, Strickler JR (1977) Encounter probabilities and community structure in zooplankton: a mathematical model. J Fish Res Bd Can 34:73-82

Haefner PA (1979) Comparative review of the biology of North Atlantic caridean shrimps (Crangon) with emphasis on C. septemspinosa. Bull biol. Soc Wash 3:1-40

Hjort $J(1914)$ Fluctuations in the great fisheries of northern Europe viewed in the light of biological research. Rapp P-v Réun Cons Perm int Explor Mer 20:1-228

Krebs JR (1978) Optimal foraging: decision rules for predators. In: Krebs JR, Davies NB (eds) Behavioural ecology an evolutionary approach. Blackwell Scientific Publications, Oxford

Laurence GC (1975) Laboratory growth and metabolism of the winter flounder Pseudopleuronectes americanus from hatching through metamorphosis at three temperatures. Mar Biol 32:223-229

Litvak MK, Leggett WC (1992) Age and size-selective predation on larval fishes: the bigger-is-better hypothesis revisited. Mar Ecol Prog Ser 81:13-24 
Lockwood SJ (1980) Density-dependent mortality in 0-group plaice (Pleuronectes platessa L.) populations. J Cons int Explor Mer 39:148-152

Markle FD, Harris PM, Toole CL (1992) Metamorphosis and an overview of early-life-history stages in Dover sole Microstomus pacificus Fish Bull 90:285-301

Miller TJ, Burke JS, Fitzhugh GR (1991) Early life history patterns of Atlantic North American flatfish: likely land unlikely) factors controlling recruitment. Neth J Sea Res $27(3 / 44): 261-275$

Miller TJ, Crowder LB, Rice JA, Marschall EA (1988) Larval size and recruitment mechanisms in fishes: toward a conceptual framework. Can J Fish Aquat Sci 45:1657-1670

Mittelbach GG, Chesson PL (1987) Predation risk: indirect effects on fish populations. In: Kerfoot WC, Sih A (eds) Predation: direct and indirect impacts on aquatic communities. University Press of New England, Hanover, p $315-332$

Modlin RF (1980) The life cycle and recruitment of the sand shrimp, Crangon septemspinosa, in the Mystic River estuary. Connecticut Estuaries 3:1-10

O'Brien WJ (1979) The predator-prey interaction of planktivorous fish and and zooplankton. Am Scient 67:572-581.

Olmi EJ III, Lipcius RN (1991) Predation on postlarvae of the blue crab Callinectes sapidus Rathbun by sand shrimp Crangon septemspinosa Say and grass shrimp Palaemonetes pugio Holthuis. J exp mar Biol Ecol 151:169-183

Pearcy WG (1962) Ecology of an estuarine population of winter flounder, Pseudopleuronectes americanus (Walbaum), Parts I-IV. Bull Bingham oceanogr Coll 18:5-78

Peterman RM, Bradford MJ, Lo NCH, Methot RD (1988) Contribution of early life stages to interannual variability in recruitment of northern anchovy (Engraulis mordax). Can J Fish Aquat Sci 45:8-16

Pihl, L (1990) Year-class strength regulation in plaice (Pleuronectes platessa L.) on the Swedish west coast. Hydrobiologia 195:79-88

Price KSJ (1962) Biology of the sand shrimp, Crangon septemspinosa, in the shore zone of the Delaware Bay region. Chesapeake Sci 3:244-255

Reichert MJM, van der Veer HW (1991) Settlement, abundance, growth and mortality of juvenile flatfish in a subtropical tidal estuary (Georgia, U.S.A.). Neth J Sea Res $27(3 / 4): 375-391$

Rice JA, Miller TJ, Rose KA, Crowder LB, Marshall EA, Trebitz AS, DeAngelis DL (1993) Growth rate variation and larval survival; inferences from an individual-based size-dependent predation model. Can J Aquat Sci 50: $133-142$

This article was presented by K. L. Heck (Senjor Editorial Advisor), Dauphin Island, Alabama, USA
Ryland JS (1966) Observations on the development of larvae of the plaice. Pleuronectes platessa L., in aquaria. J Cons perm int Explor Mer 30(2):177-195

Scott WB, Scott MG (1988) Atlantic fishes of Canada. Can Bull Fish Aquat Sci 219:731

Sissenwine MP (1984) Why do fish populations vary? In: May RM (ed) Exploitation of marine communities. SpringerVerlag, New York, p 59-94

Sogard SM (1992) Variability in growth rates of juvenile fishes in different estuarine habitats. Mar Ecol Prog Ser 85 $35-53$

Sogard SM, Able KW (1992) Growth variation of newly settled winter flounder (Pseudopleuronectes americanus) in New Jersey estuaries as determined by otolith microstructure. Neth J Sea Res 29(1-3):163-172

Tuma JJ (1989) Numerical calculations in engineering: definitions, theorems, computer models, numerical examples, table of formulas, tables of functions. McGraw-Hill, New York

van der Veer HW (1986) Immigration, settlement, and density-dependent mortality of larval and early postlarval 0 group plaice (Pleuronectes platessa) population in the Wadden Sea. Mar Ecol Prog Ser 26:223-236

van der Veer HW, Bergman MJN (1987) Predation by crustaceans on newly settled 0-group plaice Pleuronectes platessa population in the western Wadden Sea. PSZN I: Mar Ecol 35:203-215

van der Veer HW, Bergman MJN, Dapper R, Witte JI (1991) Population dynamics of an intertidal 0-group flounder Platichthys flesus population in the western Dutch Wadden Sea. Mar Ecol Prog Ser 73:141-148

Victor BC (1986) Larval settlement and juvenile mortality in a recruitment-limited coral reef fish population. Ecol Monogr 56(2): 145-160

Werner EE (1986) Species interactions in freshwater fish communities. In: Diamond J, Case TC (eds) Ecological communities. Harper and Row, New York, p 344-358

Werner EE, Gilliam JF, Hall DJ, Mittelbach GG (1983) An experimental test of the effects of predation risk on habitat use. Ecology 64(6):1540-1548

Wilcox JR, Jeffries HP (1974) Feeding habits of the sand shrimp Crangon septemspinosa. Biol Bull 146:424-434

Williams PJ, Brown JA (1992) Developmental changes in the escape response of larval winter flounder Pleuronectes americanus from hatch through metamorphosis. Mar Ecol Prog Ser 88:185-193

Witting DA, Able KW (1993) Effects of body size on probability of predation for juvenile summer and winter flounder based on laboratory experiments. Fish Bull 91(3):557-581

Manuscript first recelved: August 12, 1993

Revised version accepted: February 7, 1995 